\title{
USERS' PERCEPTION AND POST-CONSERVATION EVALUATION OF KAMPUNG TELUK MEMALI MOSQUE IN IPOH, PERAK, MALAYSIA
}

\author{
AZIM A. AZIZ \& M. HAZIQ ZULKIFLI \\ ATSA Architects, Kuala Lumpur, Malaysia
}

\begin{abstract}
The 108-year-old traditional Malay timber mosque structure, Kampung Teluk Memali Mosque has been successfully relocated and restored to a new site in an urban township of Ipoh city in Perak state, Malaysia. The conservation process of the mosque has been fully anticipated by the local community of both old and new site until its completion by the end of the year 2017. In 2018, the building has received its official certification from the local authority, and a handover ceremony has also been held to the rightful landowner, as well as the local community. This is a subsequent study to the previous relocation and conservation programme of the mosque, with the aim of investigating on the users' perception and post-conservation evaluation in terms of the aspects of comfortability, awareness and maintenance. The study is vital in engaging future conservation project in a similar approach, involving any built heritage structures with direct community participation.
\end{abstract}

Keywords: conservation, evaluation, mosque, timber, users.

\section{INTRODUCTION}

After efforts of more than 3 years, the historic timber mosque of Kampung Teluk Memali has finally come to fruition. The mosque has now been serving the local Muslim community of around 100 people as a local surau (small mosque) in Taman Seri Bougainvillea, Bandar Seri Botani in the city of Ipoh, Perak. The mosque's unique feature of the Perak traditional architecture now stands out harmoniously in the urban township area, with the original building elements are seamlessly intact, without any juxtaposed additions (Fig. 1).

The initial relocation mosque programme was deemed as nearly impossible as many hurdles were expected, right from the earlier permission, relocation, timber treatment and reinstallation programme, but most importantly, financial factor in actualising the whole process. The limited funding has hampered some of the processes, but it had not put an end to the whole conservation process.

With the new conserved mosque is being used and fully functioned for various communal and religious activities for about a year, it is timely to investigate the users' perception and post-conservation evaluation of the building. The local community has been anticipated for a new place of worship in their neighbourhood for the past 5 years, so their overwhelming response was highly cited, but how it was unfolded upon the mosque completion remain unknown.

\section{LITERATURE REVIEW}

Adapting heritage building to the new site and usage can be challenging on how it can be adjusted and suited to the current expectation. Also, a successful conservation programme must have a compatible use in place, and retain its historic character and conserve significant fabric, but it can still introduce new services as well as modifications and additions [1]. 


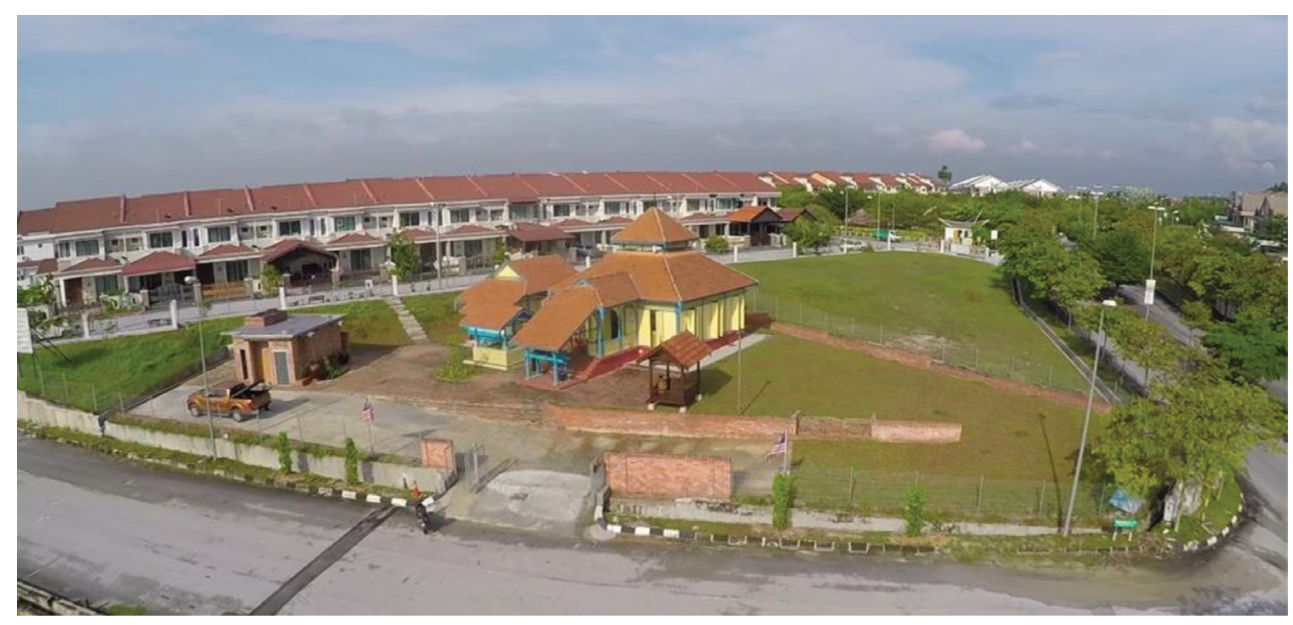

Figure 1: Aerial view of Kampung Teluk Memali Mosque in Ipoh, Perak, Malaysia.

With the lack of exposure and knowledge on the usage of heritage buildings, the public as end users may find it difficult to adapt it to current or modern lifestyle. Furthermore, the heritage conservation efforts in Malaysia may seem only belonged to a group of specialised people - building professionals and experts, but not the public at large [2]. To further develop conservation filed in this country, more concerted efforts should be encouraged to involve the public in the scene - in terms of promotion, education, awareness and even direct participation.

The public interest and participation in conservation very much depend on its initial stage. The public interest (or disinterest) in a heritage building conservation depends on its initial state of conservation [3]. He highlighted that the very bad state the building is, the public and the stakeholders involved are likely to neglect it. This will spur the further deterioration of the heritage building, while inversely, a good condition will create a positive response and stir up more interest and attention, resulting in the increase resources allocated for its conservation.

\section{AIM AND OBJECTIVES}

This study is aimed to examine the users' perception and post-conservation evaluation of the relocation and conservation of Kampung Teluk Memali Mosque in Ipoh, Perak, Malaysia. To further investigate and achieve the study aim, the study objectives have been outlined in terms of the aspects of comfortability, awareness and maintenance.

\section{RESEARCH METHODOLOGY}

Several methods were used to obtain the research objectives of this study. The primary data were collected through face to face semi-structured interviews with the local community of Taman Seri Bougainvillea neighbourhood, of whom most are the end-users of Kampung Teluk Memali Mosque. This is the best method for collecting data required to be examined and determined based on the three main indicators.

Based on the accumulated data and information from the literature review and the field research, it has been analysed and leads to the findings. Then, it leads to the fruition of results and conclusion, presented with several recommendations. 


\subsection{Questionnaire Distribution}

A set of semi-structured questionnaire was prepared and used in surveying the users' perception and review of the mosque in the post-conservation stage. The Muslim community of Taman Seri Bougainvillea in Bandar Seri Botani, Ipoh, Perak, especially the mosque committee members and mosque users were selected as the target group for this questionnaire. They were specifically selected based on probability simple random sampling in order to get a broad perspective of all mosque users.

As their numbers were small, plus with their limited time available for the interview, due to their status as full-time employees in government and private sectors, only 54 respondents were interviewed for this study. Nevertheless, this was instrumental and essential to extract accurate data collection for the study.

\subsection{Questionnaire Design}

The questionnaire was divided into four sections that look into the respondents' general background, overall existing building conditions, comfortability and mosque building functions and users' feelings and future conditions of the mosque. Each question is presented with multiple choice answers, as well as linear scales from one to five, with five represents the best when it talked about the general mosque conditions, comfortability and feelings towards the mosque.

The first section talked about the respondents' gender, age and visiting frequency. While in the second section delved into the user's view on the general conditions of mosque building, of each facility provided, as well as the maintenance side. In the third section, the questionnaire looked into the comfortability and usage aspects, on how it can be further improved and upgraded. In the last section or the fourth section, it explored the users' attachments and feelings towards the mosque and how the mosque would be in the future.

\section{RESULTS AND DISCUSSION}

\subsection{Users' Demography}

Based on the respondents' background, it can be analysed that the majority of the respondents are male from the age group of 31-40 years old, with $77.8 \%$ and $55.6 \%$ respectively. They are also frequent users with $62.5 \%$ use the mosque on a daily basis. Thus, it can be inferred that the majority of the users are youth (below 40 years) and also served as the main breadwinner for their young and small family, with a couple of numbers of children. This is vehemently apprehensible as most of them are full-time employees in both government and private sectors.

\subsection{Overview of the Existing Building Conditions}

As a heritage and a century old age building, the Kampung Teluk Memali Mosque had used to stand sturdily despite the dilapidated conditions on its former site in Kampung Gajah, near the Perak River in Central Perak district of Perak state. Being abandoned for the past 20 years, it had withstood against all elements without major defects and deterioration. Since last year, the mosque has been given a new fresh lease of life with the relocation and restoration of its 
mosque building components. Every single part has been preserved, replaced or make good with additions of new and modern facilities on the new site.

Therefore, the end-users were asked for their opinion about the current conditions of the mosque building in the post-conservation stage. In this second section of the questionnaire, four questions were raised, with the answers selection were posted as on a linear scale, with one is not satisfied, and five is the best condition. Based on the question, the majority of the respondents, with $50 \%$ of them agreed that the mosque in good condition. While $37.5 \%$ of the respondents, however, believed it is in a satisfactory condition, and only $12.5 \%$ of respondents thought the mosque in its best condition.

In this regards, the majority of the end-users believed the mosque is still in good condition, in this post-conservation stage. This is reckoned as the mosque has been used for a year, as it is still in an infancy stage. Besides that, a proper conservation procedure was established and done in the rebuilding of the mosque to ensure that the mosque can be re-used and repurposed as an Islamic place of worship for the next 100 years (Fig. 2).

Meanwhile, in the next question, every single facility of the mosque was evaluated with each facility was listed in the answer options as multiple checkboxes. All 14 main facilities were listed with one option for others for the question. Based on the survey, the data obtained are tabulated as per below in Fig. 3 .

In this data tabulation, each facility has been evaluated with most of the respondents believed that the toilet could be further upgraded with $15 \%$ had voted for it. This is followed by an ablution water trough (kolah), connecting wooden walkway, landscaping and building structures, such as roof, wall and columns at $10 \%$ each. The gazebo and green area were ranked in the third place at $7.5 \%$ respectively.

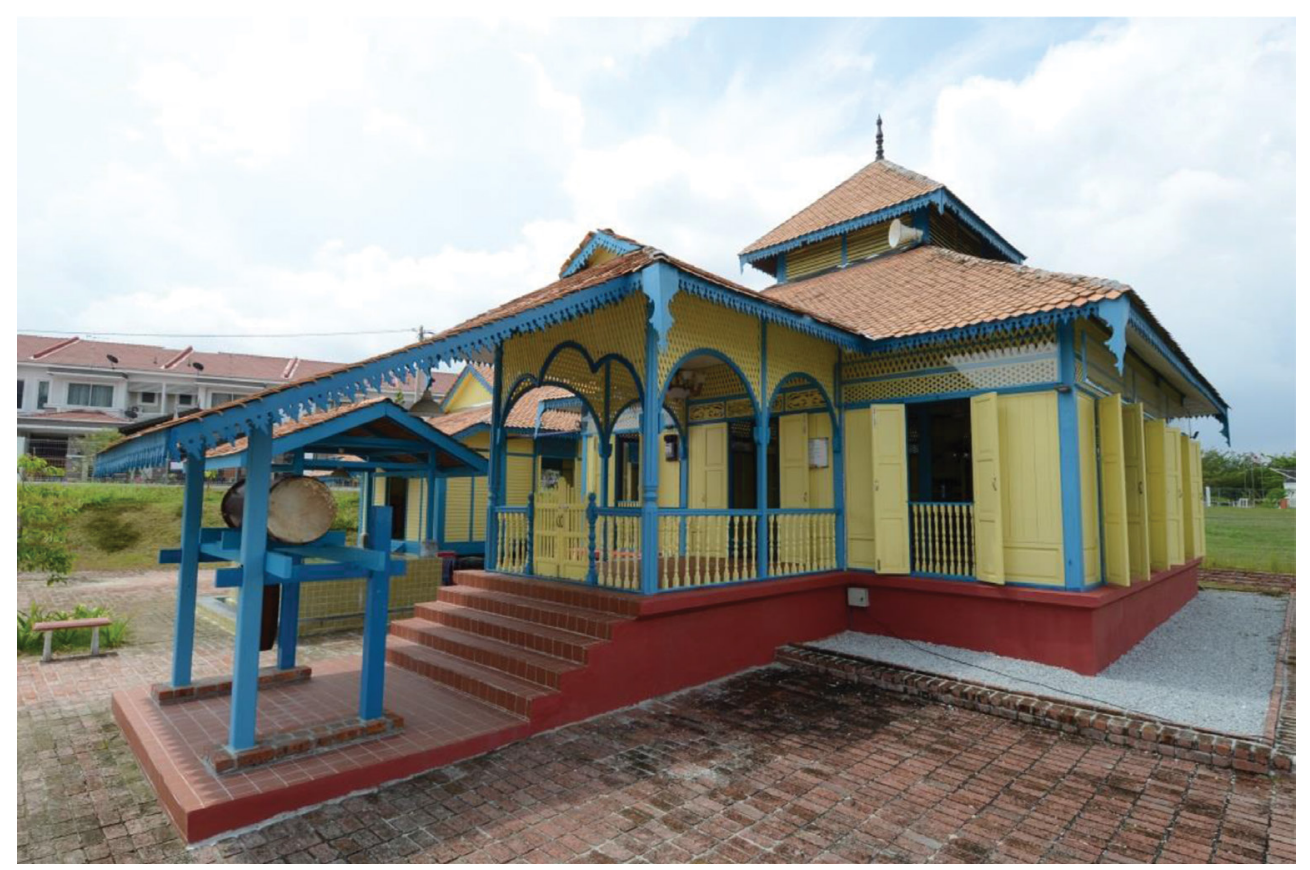

Figure 2: Conditions of mosque building after the completion of conservation works. 


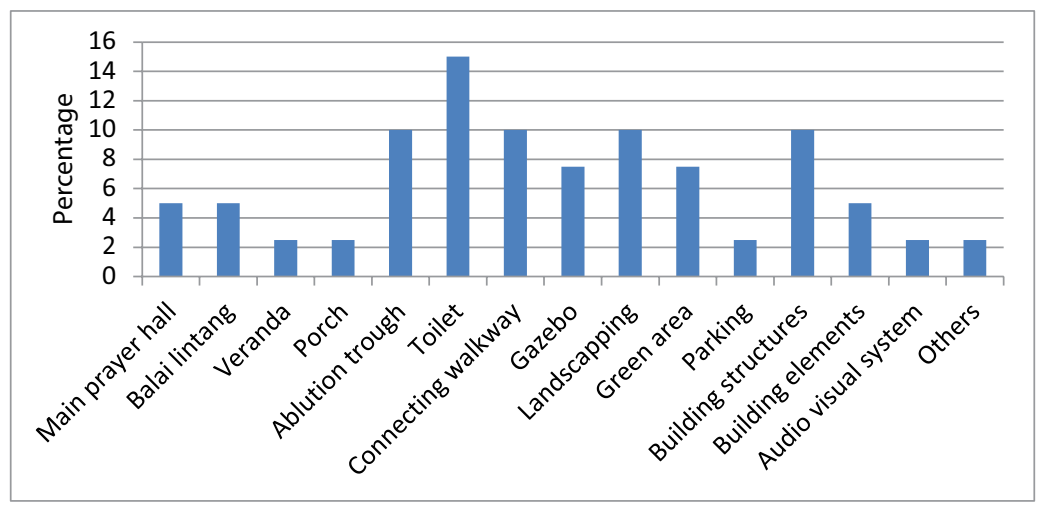

Figure 3: Users' opinion on facilities upgrading for the mosque.

The end-users concern on the toilet can be understood from its lack of maintenance, as well as some issue during and after the construction. The toilet building is a new addition to the mosque as a modern facility for ablution and washing purposes (Fig. 4). Unfortunately, it had not been executed properly by the appointed contractor as they were issues on workmanship and leaking at certain parts. Even though it had been rectified, some minor issues were surfaced from time to time, such as water accumulation, clogging and leaking pipes, etc.

On the next question, $100 \%$ of respondents agreed that the mosque needs maintenance from time to time. Just like any other buildings, the Kampung Teluk Memali Mosque also needs a sensible and workable maintenance plan for a certain period. This shall cover including the conservation aspect of maintenance, such as the Singgora roof tiles, timber wall panels and timber balustrades.

In the final set of question in the second section, respondents were asked about what kind of maintenance needed for the mosque. Seven options of answer were provided, including the

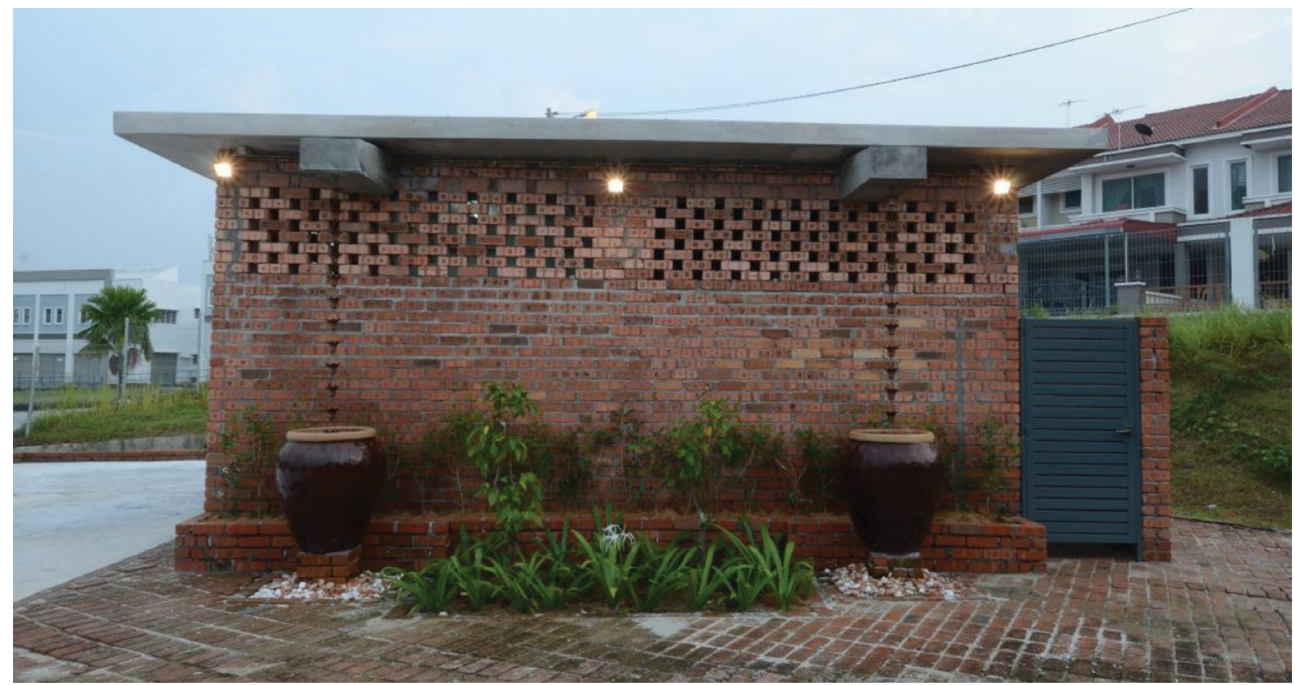

Figure 4: The new toilet building. 


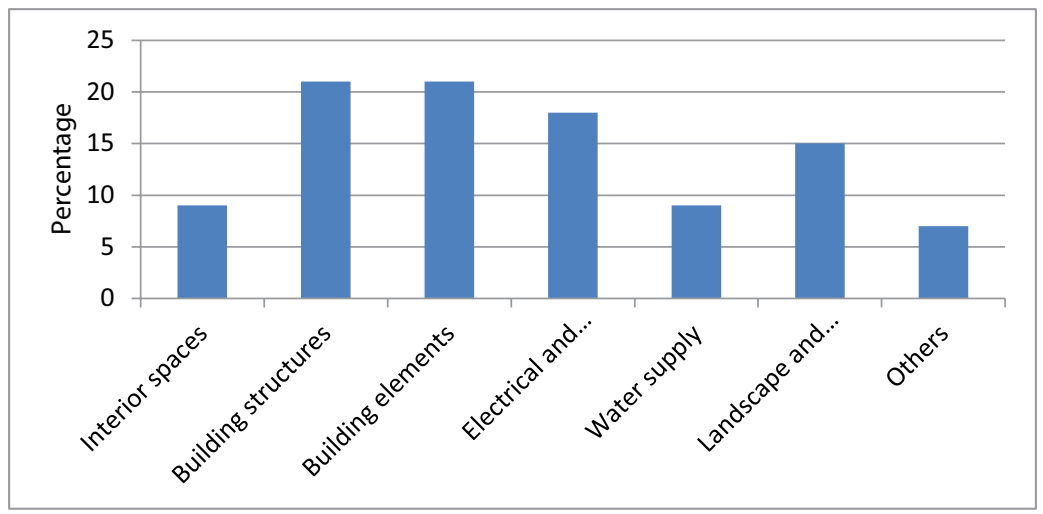

Figure 5: Maintenance aspect for the mosque building.

maintenance of interior spaces, building structures, building elements, electrical and mechanical, water supply, landscape and compound area and others. The data obtained is presented as below in Fig. 5.

The majority of respondents opined that both building structures and elements needed to be maintained with the most at $21 \%$ respondents opted for these options. The building structures refer to the building structural components such as the wall panels, columns, roof and beams, meanwhile the building elements refer to the components such as the windows, doors, ventilation panels, mihrab and floor. Their concerns are valid for this is a heritage building, rigorous and regular maintenance work is necessary to ensure the longevity of the building components and materials, as they are mainly made of timber.

This is followed by the electrical and mechanical whereby $18 \%$ respondents had ticked for this option that needs to be maintained as well. Meanwhile, $15 \%$ of respondents thought that the landscape and compound area need to be upkeep. The mechanical and electrical refer to the electrical supply, including the provision of fans and lightings, as well as the audio-visual system. This aspect ought to be maintained at some point, but not at a frequent interval.

\subsection{Building Comfortability and Functionality}

The success of any buildings can be measured from its usage and users' responses towards its functions and purposes. In this section of the questionnaire, this aspect was investigated upon the users of Kampung Teluk Memali Mosque. As a public place of worship, the mosque has drawn users and visitors locally and abroad (Fig. 6). As it is located in a modern neighbourhood, the mosque is easily accessible due to its strategic location in the suburb of Ipoh city, the capital city of Perak state.

The first question asked about the comfortability aspect, whether the users felt comfortable in using the mosque as a place of worship. The whopping number of $87.5 \%$ respondents agreed that the mosque is comfortable to be used at any time, and another $12.5 \%$ felt very comfortable while using the mosque. The comfortability aspect, especially when performing prayers inside the main prayer hall, is the key aspect, with proper and adequate lighting and ventilation have been provided by the architect cum mosque developer, ATSA Architects.

In the next question, respondents were asked about which part or area of comfortability in the mosque can be uplifted. Seven answer options were listed for this question, which 


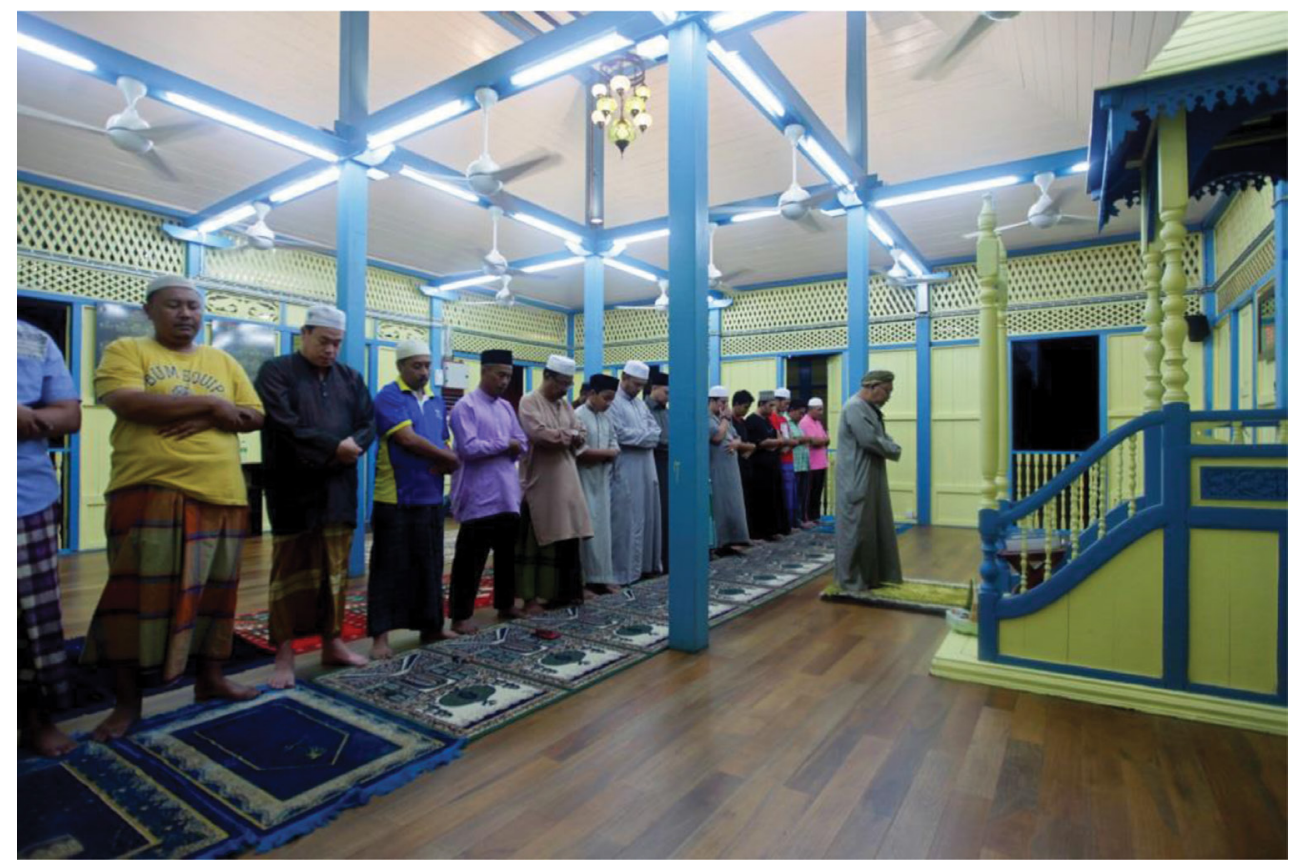

Figure 6: Worshippers performing prayers inside the main prayer hall.

includes the prayer area, interior lighting, interior ventilation, ablution area, toilet, storage space and others. The data acquired is tabulated as per below in Fig. 7.

As indicated in the table, the comfortability aspect in the toilet has the biggest vote among the respondents with $28 \%$ believed it should have been upgraded. This is consistent with the previous maintenance aspect whereby the toilet also needs to be upkeep regularly. As mentioned in the previous subchapter, there seem to be a few issues with the construction of toilet building.

Ablution and storage space comes in the second place with $20 \%$ respondents picked it up. Comfortability for the ablution area can be translated as probably bigger space or more water tap for ablution. It can also be in terms of the space of ablution point or walkway from

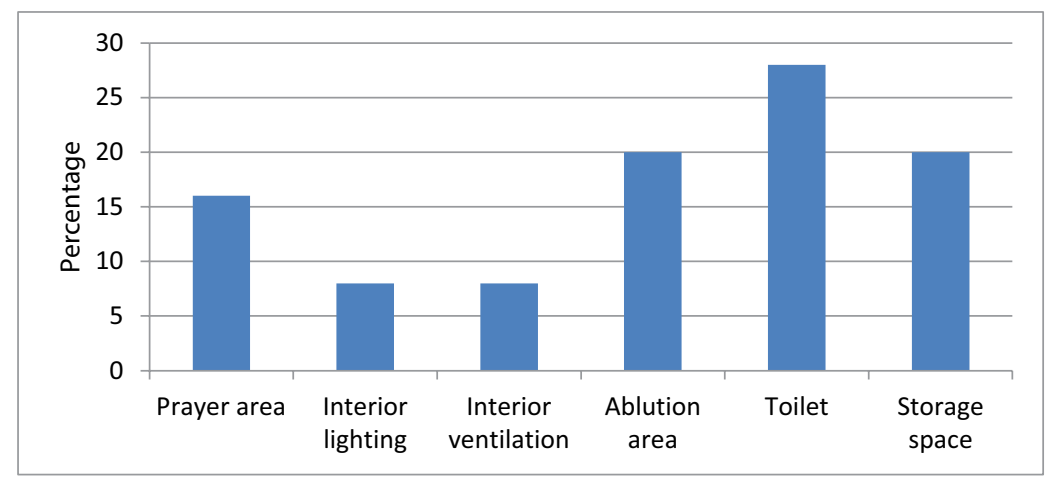

Figure 7: Spaces comfortability of the mosque. 


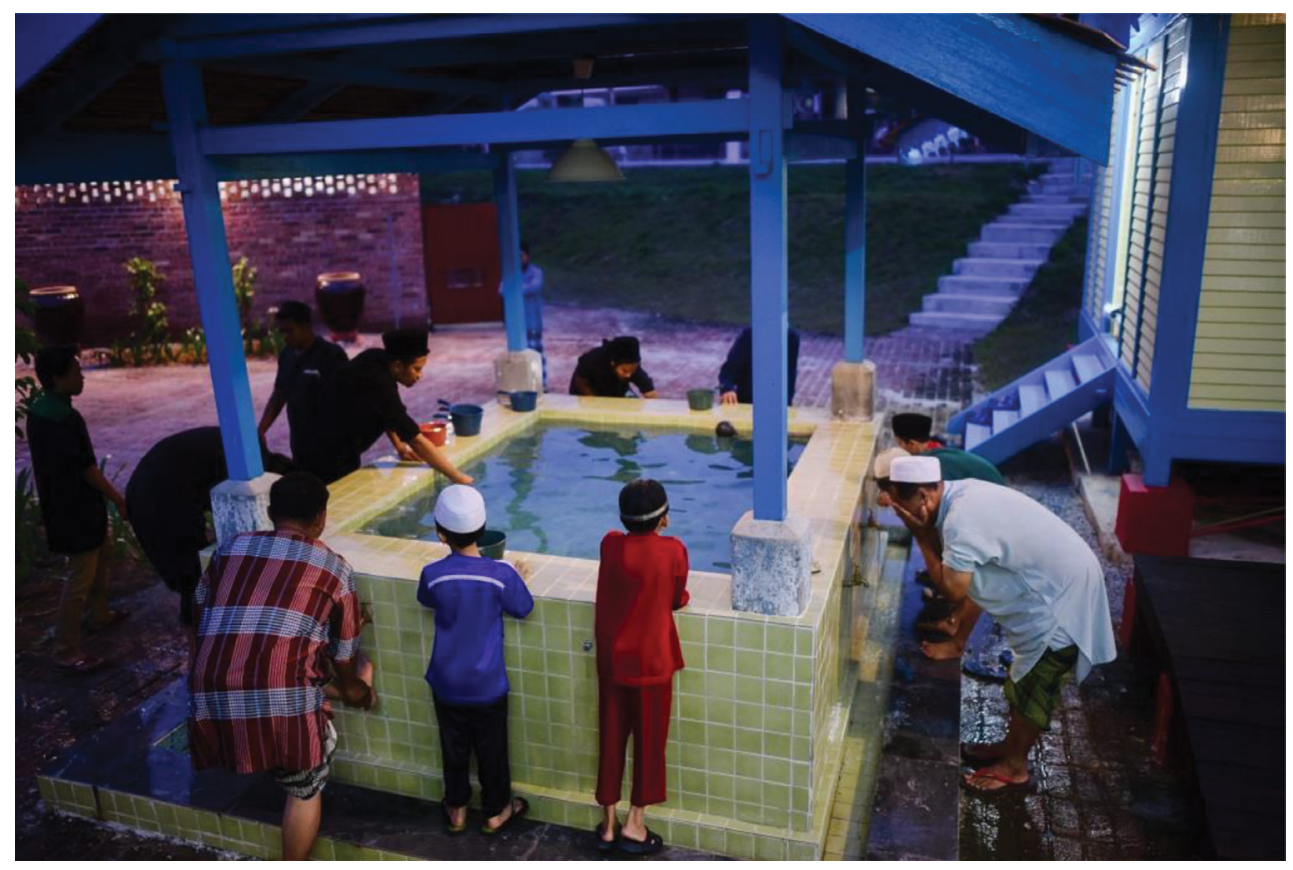

Figure 8: Ablution water trough.

ablution to the prayer hall (Fig. 8). While for the storage space, as there is currently a medium size storage space in the toilet building, the respondents felt that the space size could be further expanded to accommodate their cooking utensils and other stuff.

In the third question, users were asked on the primary functions of this building. As a mosque, the majority of the respondents without hesitation chose its primary function as a public place of Islamic worship at $55.6 \%$ as per below pie chart (Fig. 9).

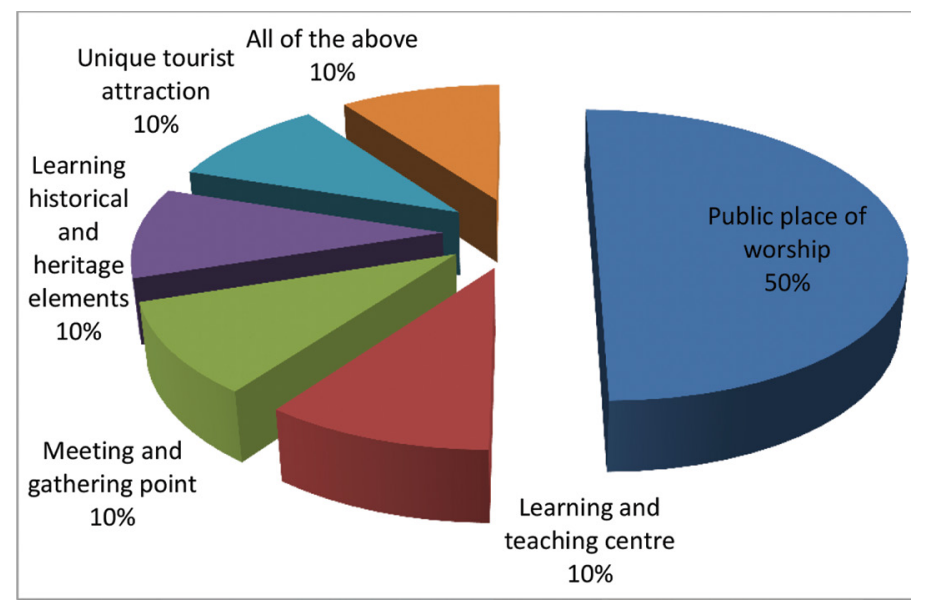

Figure 9: Primary functions for the building. 
This is predictable as the structure itself is a mosque building that has been established since the early 20th century. The building was and will always be a public place or worship, as it is now the main surau (small mosque) for the community, but not as a full-fledged mosque, as Friday prayers are not conducted here.

Other than being used as a surau, other respondents were equally believed the building's primary function between as learning and teaching centre, a meeting and gathering point, a place to learn the history and heritage elements, particularly on the mosque itself and a potential unique tourist attraction. The vote is split evenly at $10 \%$ each with another $10 \%$ also believed all of the above.

As an eclectic built heritage, the Kampung Teluk Memali Mosque itself is a tapestry of unique Malay culture, arts, heritage and architecture that is hardly seen nowadays, especially in an urban area like Ipoh city and other major cities in Malaysia. It is currently the only traditional timber mosque of Perak Malay architectural features that still stands without any major changes in its essential elements and its original form in the city. It has a huge potential to become another heritage-based tourist attraction for the city and state.

In relations to the historical and heritage elements of the mosque, the respondents were asked about their knowledge about the mosque's history and significance. The greater number of respondents at $88.9 \%$ admitted that they know the mosque's history and its significance, while another $11.1 \%$ thought that they might know. This is expected as the mosque's unique history, and architectural significance is often highlighted during the conservation process by various media outlets, be it printed, online or social media. The publicity and promotion exercises were an integral part of the public donation and crowdfunding for this conservation effort, as it was a non-profitable and charitable conservation effort that solely dependent on public funding from various organisations and individuals.

In terms of heritage properties for the mosque, the next question raised about its significance and ability to be listed under the Department of National Heritage (JWN). Similar to the previous response, about $88.9 \%$ of respondents believed the mosque could be listed under the JWN, while another $11.1 \%$ thought it might be done so.

In Malaysia, the JWN's role is guided and rolled out by Act 645, the National Heritage Act 2005, that encompasses the act of conservation and preservation of the national heritage, natural heritage, tangible and intangible cultural heritage, underwater treasures and cultural heritage and related matters [4]. In Section 24 of the act, it spells out the Heritage Commissioner's vested power in declaring any natural or cultural heritage sites of historical significance and other high values to be a heritage site [5]. In this regards, the mosque has a high value of historical and architectural significance that should be listed and gazetted as a heritage site.

While it may be true that the majority of the respondents suggested the building should be listed as a heritage building, they may have no idea what the heritage listing might be beneficial or positive impacts towards the building. In the last sixth question of the third section, the question asked the respondents on the benefits that the building will enjoy in the future post-listing. The collected data are charted as per below in Fig. 10.

The majority of the respondents were hopeful that the listing would bring financial assistance from the government at $27 \%$ of them. This is followed by an official recognition from the government at $23 \%$. Meanwhile, another $17 \%$ of respondents opted for both the assistance for technical advice and potential tourist destination options.

Few benefits can be gained from the heritage listing for any buildings or sites. One of them is regarding financial aspect, whereby the owners or occupants may be able to receive 


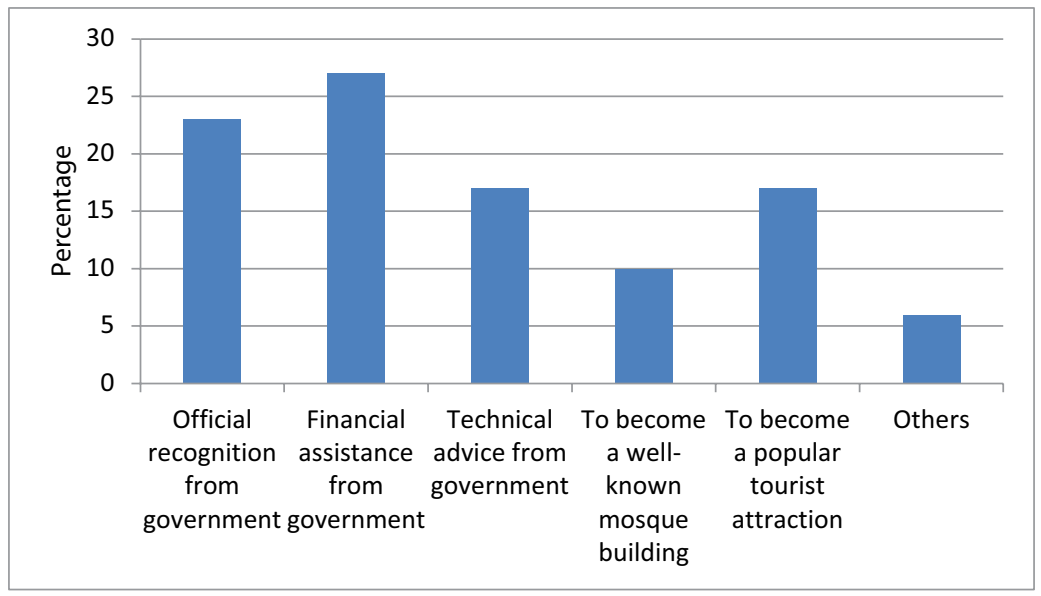

Figure 10: Benefits of heritage listing for building.

financial assistance to maintain and preserve the site [6]. However, the financial assistance is subject to the availability and fund balance and approval of the Heritage Commissioner.

Other than the financial aspect, the JWN may offer technical advice to the site owners or occupants in terms of conservation, preservation, maintenance and other related matters. On top of that, through heritage listing on the site or building, it will enable the site or building owners to generate income and potential to become a tourist attraction destination [7].

\subsection{Personal Attachments and Future Plan for the Mosque}

In the last section of the questionnaire, it investigates the personal attachments and feelings of the respondents towards the mosque building as a whole. In the first question, the respondents were asked about the feelings, whether they were proud of using the mosque. The huge number of respondents at $88.9 \%$ were proudly using the mosque, while the remaining $11.1 \%$ thought that they might be proud of it. This is an unsurprising data collection as the mosque itself is a peculiar and built heritage gem of Ipoh city.

This further translated into the next question that asked whether the respondents loved or liked the mosque. This is a whopping overwhelming response that saw $62.5 \%$ of respondents loved or liked the mosque very much. This is followed by the $37.5 \%$ loved or liked the mosque based on the linear scale from one to five, with one is the least love or like. This finding is echoed to the previous question that queried at the end-users feelings or attachments towards the mosque, which is overwhelming affections towards the mosque.

For the next question, the respondents were asked about whether the mosque should have been conserved and preserved. Surprisingly, the respondents were unanimously agreed that Kampung Teluk Memali Mosque should be conserved and preserved for next generations at $77.8 \%$ vote, while only $22.2 \%$ thought that it should be preserved to be used as a place of worship or mosque. The data collected shows that the majority of the respondents agreed that as a heritage building, Kampung Teluk Memali Mosque should be safeguarded and protected for the next generations.

In the final question for the questionnaire, the respondents were asked for their suggestions about the mosque improvement in the future. As the final question, this question delved into 


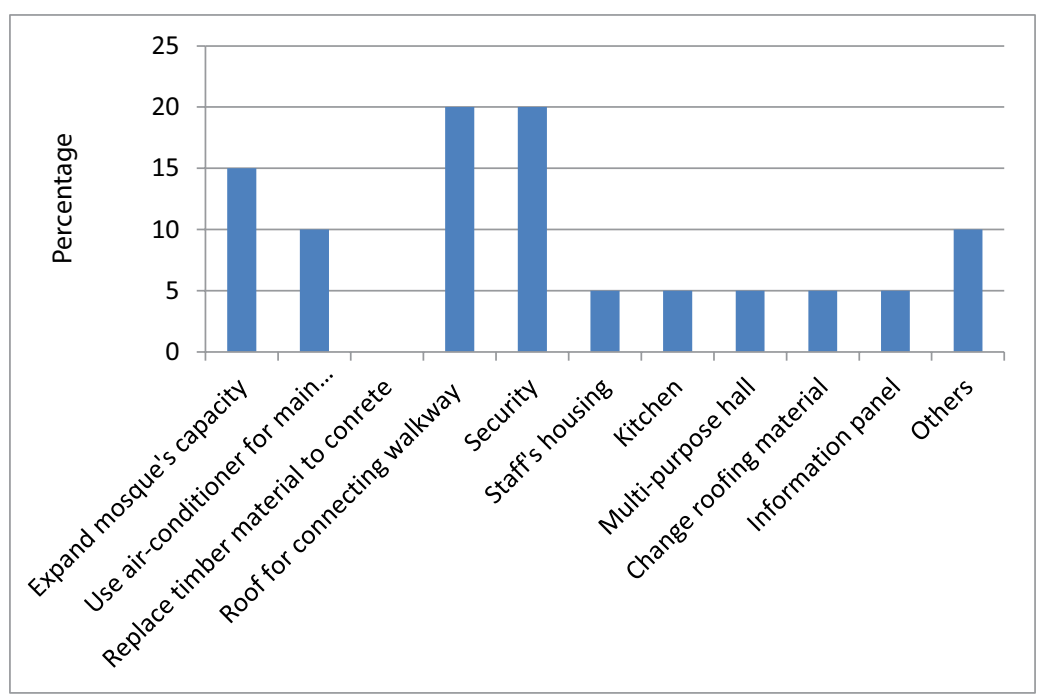

Figure 11: Suggestions for future improvements of the mosque.

what kind of aspect that can be added or created for the mosque, as a future improvement. Below are the answers gathered from the respondents in Fig. 11.

The majority of the respondents suggested a roof should be built for the timber connecting walkway, between the main prayer hall and balai lintang, and also the provision of security at $20 \%$ vote, respectively. This is followed by the expansion of the mosque's capacity, particularly in the prayer hall area, whereas $15 \%$ respondents suggested for this option. Despite the use of fans in the main prayer hall and balai lintang, some $10 \%$ of respondents also opted for the provision of air-conditioner in the prayer area.

Based on this question, the end-users' main concern for the mosque in the future can be indicated on their suggestion for a covered roof for the connecting walkway between the main prayer hall and balai lintang. This is reasonable as they currently had to cross between the prayer spaces back and forth in the elements (Fig. 12). Meanwhile, the security aspect has also been emphasised by the respondents since the security and safety of the mosque's property and end users are the utmost importance. Nonetheless, to upkeep with the current and modern lifestyle, some respondents still prefer the cold air of the air conditioner over the electric fan.

\section{CONCLUSION AND RECOMMENDATIONS}

In conclusion, through this study, it has led to the result of the investigation on the users' response and post-conservation conditions of the Kampung Teluk Memali Mosque in Ipoh, Perak, Malaysia. The result of the study has given a clearer picture for the researchers on the evaluation of the relocation, conservation and preservation for Kampung Teluk Memali Mosque, especially from the perspective of end-users in the post-conservation stage.

The mosque is generally in good condition; with all facilities are still functioning and in good states [8]. However, some of the facilities were lack of maintenance, such as toilet, despite a few construction and workmanship issues that an architect/developer met with the contractor last time. Besides that, some respondents also raised maintenance issues for the 


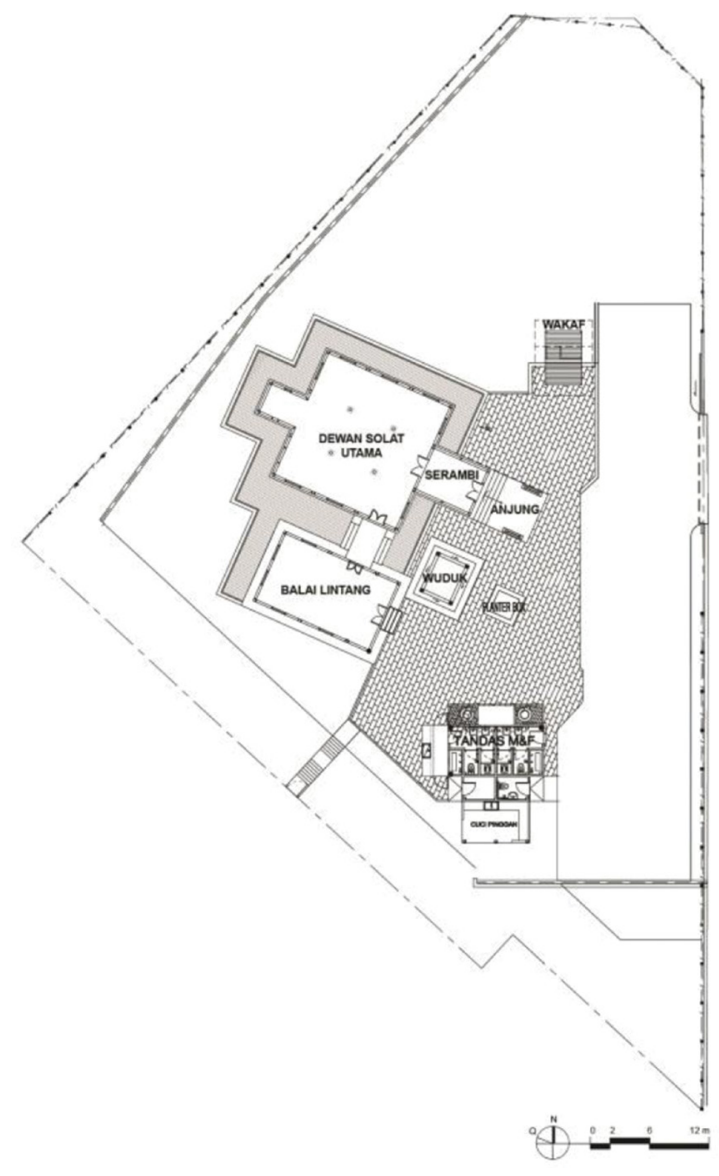

Figure 12: Floor plan and site plan of the mosque.

building structure and elements, with most of them were made of timber and clay (roof tiles) that needed to be upkeep from time to time. Therefore, a continuous and exhaustive maintenance plan must be established and executed by the mosque committee to ensure all of the facilities in good condition and function properly.

The end-users were generally comfortable in using the mosque and have strong attachment feelings to the mosque, as they fell in love and proud while using and owning the mosque as a community. However, they still treat the mosque primarily as a public place of worship over anything else. Hence, they have suggested for mosque future improvements, including a covered connecting walkway and security services.

In terms of conservation, the local community of Taman Seri Bougainvillea was wellaware of the mosque's historical and heritage significance and strongly agreed on the gazetting of the mosque as a heritage building under the Department of National Heritage (JWN). They even strongly believed that the mosque should be conserved and preserved for the next generation, over other reasons. This shows that the end-users, which are the local community has a high level of awareness of the conserving and preserving the heritage and old buildings. 
Nevertheless, the community must be assisted and educated in terms of maintenance and continuous preservation efforts of the building under a sound and exhaustive Conservation Management Plan (CMP) that can be utilised under the JWN, Islamic Religious and Malay Customs Council of Perak (MAIPk) as the landowner and the local authority, the Ipoh City Council (MBI). Ultimately, the local community can also reap benefits from the heritage building status in terms of economic gain from the overspill effects as a potential heritagebased tourist destination of Ipoh city in Perak state, Malaysia.

The Kampung Teluk Memali Mosque has tremendously contributed to the local Muslim populace of Taman Sri Bougainvillea and its surrounding area. Apart from its primary use as the main place of worship (as a surau or small mosque) for daily congregational prayers, it is also actively used as the communal centre for teaching and learning purposes, outdoor and recreational activities, such as archery, silat (traditional Malay martial arts) and gathering and feasts during Eid, special prayers and occasions, such as korban (sacrificial) matrimonial and circumcision ceremonies. As it exudes a truly pristine of authentic traditional Malay architecture, the mosque has easily been chosen as the famous and new photographic spot in the city, other than being the latest tourist attraction of the city of Ipoh and the state of Perak in northern Malaysia.

\section{ACKNOWLEDGEMENTS}

The authors would like to extend gratitude over the cooperation rendered by the committee members of Kampung Teluk Memali Mosque and the local community of Taman Seri Bougainvillea in Ipoh, Perak, Malaysia, during the interview process of data collection.

\section{REFERENCES}

[1] Adaptive Re-Use; Modern Heritage Matters. modernheritage.com.au/mhm/heritage_issue/another-title-to-go-here-5/. Accessed on: 27 September 2018.

[2] Harun, S. N., Heritage Building Conservation in Malaysia: Experience and Challenges. Procedia Engineering 20, Elsevier: Amsterdam, pp. 41-53, 2011.

[3] Greffe, X., Is Heritage an Asset or a Liability? Journal of Cultural Heritage, Elsevier: Amsterdam, pp. 301-309, 2004.

[4] National Heritage Act 2005 (Act 645); Department of National Heritage. www.heritage.gov.my/ms/kenali-kami/akta-warisan-kebangsaan-2005. Accessed on: 8 October 2018.

[5] Commissioner for Law Revision, Laws of Malaysia - Act 645, National Heritage Act 2005, Malaysian National Print Berhad: Kuala Lumpur, 2006.

[6] Yusoff, M.Y.M. \& Hanafiah, M.G., National Heritage Act 2005 (Act 645): Evaluation from Legislation and Enforcement Aspects. The Malay Journal, UKM Press: Bangi, pp. 202-223, 2015.

[7] Ibrahim, J.A. \& Ahmad, M.Z., Tourism Planning and Development, Northern University of Malaysia Press: Sintok, 2012.

[8] Aziz, A.A. \& Zulkifli, M. H., The Relocation, Conservation and Preservation of Kampung Teluk Memali Mosque in Kg. Gajah, Perak to Ipoh, Perak, Malaysia. WIT Transactions on The Built Environment 177, WIT Press: Southampton, pp. 181-192, 2018. 